\title{
IMPLEMENTATION OF GRAMEEN BANK PATTERNS IN INCREASING AND STRENGTHENING THE MIDDLE ECONOMIC SECTOR POST-ERUPTION OF KELUD MOUNTAIN
}

\author{
Muhammad Khoirul Fuddin \\ Department of Economic Development, Faculty Economic and Business, University of \\ Muhammadiyah Malang \\ Email: khoirul.fuddin@gmail.com
}

\begin{abstract}
The natural disasters of the Mount Kelud eruption that occurred in Malang Regency in 2014 had a negative impact on the economic conditions and the level of welfare of the communities affected by the eruption. After the eruption of Mount Kelud as a large part of the community that became victims will begin the condition of their economic activities starting from the beginning considering that most of the capital and production factors owned have been damaged and destroyed by the eruption. Meeting capital requirements is a major problem in starting the economic activities of the surrounding community. Capital adequacy by making loans to banking institutions is considered difficult by the community because the community is considered not bankable by financial institutions. The research methodology used in this study is to use descriptive methods by using literature review from various sources and data. The results of this study conclude that the capital shortcomings and difficulties experienced by the surrounding community after the Mount Kelud eruption can be overcome by implementing the Grameen Bank pattern, where the pattern is considered effective and in accordance with the conditions and attitudes of the community that uphold mutual cooperation and family values because of the Grameen Bank pattern adhering to a joint responsibility system.

Keywords: grameen bank, eruption, tanggung renteng
\end{abstract}

\section{INTRODUCTION}

The Kelud eruption that occurred in mid-February 2014 was a natural disaster which became a nightmare for residents around the district. Malang especially the Ngantang region where the area was most affected by the eruption of Mount Kelud. Based on data collection in Malang Regency, the direct impact of Mount Kelud eruption caused a loss of Rp. 392.66 billion. The number of fatalities in Malang Regency was $7 \mathrm{died}, 31$ people were hospitalized, and 1,392 people were outpatient. (National Board for Disaster Management).

Damage to the building included 3,782 units of houses, 20 government buildings, 25 units of educational infrastructure, 9 units of health infrastructure, 36 units of worship, and $8,095 \mathrm{~m} 3$ of clean water damage. The areas most affected by eruptions in Malang Regency are in Ngantang and Kasembon Districts. Damage to agricultural land consists of rice fields with an area of 5,146 ha, 1,792 ha of agricultural land, and 
260,060 trees of fruit trees. Whereas there are 25,290 dairy cows affected. (National Board for Disaster Management).

A serious problem that became a common concern after the eruption of Mount Kelud was the paralysis of the economic system found in the area. Whereas previously the Malang regency areas affected by the eruption, such as Pujon, Ngantang or Kasembon, were highland areas capable of producing horticultural products and were cattle breeding areas. The main results include vegetables, fruits and cow's milk. Even Pujon cow's milk is a supplier of Nestle's large cow milk companies in Pasuruan with a high level of productivity of 99.4 liters per day. Whereas the Ngantang area is an agricultural area that also contributes various types of agricultural products such as rice, vegetables, fruits and even ornamental plants. While Kasembon is a durian-producing region that is able to bear fruit regardless of season.

With the disaster of the Mount Kelud eruption, the people or victims of the disaster must automatically start their businesses from the beginning. To re-start a business clearly what is needed first is business capital. Classical problems arise, where in fulfilling capital adequacy it will be difficult to achieve if the community is considered not bankable by financial institutions. For the community our usual requirements with $5 \mathrm{c}+3 \mathrm{R}$ are difficult to fulfill, where 5C stands for Character (moral), Collateral (additional collateral), Capital (own capital work / effort), Capacity (ability to pay), Condition (productivity). While 3R stands for Return (the results to be obtained), repayment (ability to pay) and Risk (risk). There is no single condition that is able to be fulfilled by the people affected by the Kelud eruption in fulfilling business capital because most of their wealth is lost or damaged due to the eruption of Mount Kelud.

The community after the Mount Kelud eruption disaster has a serious problem in the long term in the form of capital adequacy in rebuilding the level of the economy in each individual or family. Financial institutions, both banks and nonbanking institutions, will also have the risk of even having difficulty in providing access to financing to communities affected by disasters because the community is considered not bankable according to the banking perspective. If this continues, the poverty in Malang Regency will increase and the welfare of the community after the eruption of Mount Kelud will be difficult to materialize. 


\section{METHOD}

The research method used in this study is descriptive research. Descriptive research is one research method that is widely used in research that aims to explain an event. As stated by Sugiyono (2011) "Desktiptif research is a study that aims to provide or describe a situation or phenomenon that occurs today by using scientific procedures to answer the actual problem". Whereas, Sukmadinata (2006) states that descriptive research method is a method that attempts to describe, interpret something, for example conditions or relationships that exist, opinions that develop, ongoing processes, consequences or effects that occur or about ongoing trends.

From the two meanings, it can be said that the descriptive research method is a method used to describe, interpret a phenomenon, for example conditions or relationships that exist, opinions that develop, using scientific procedures to answer the problem actually. Thus, researchers assume that the descriptive research method is in accordance with the research carried out by the researcher. Because in this study, the researcher tried to describe and provide a suggestion and solution to increase and strengthen the lower middle economic sector in Malang district after the eruption of the Kelud mountain using the implementation of the grameen bank pattern.

\section{DISCUSSION}

\section{Solutions Offered}

Financial institutions whether banking or non-banking will think a thousand times in providing credit facilities to disaster victims to conduct new business activities. The activity behavior of this institution is not entirely wrong, but when the community does not get access to credit, it means that the economic community of the community after the disaster will suffer, which in the end will be difficult to fulfill the level of community welfare. To overcome this problem, the researcher offers a pattern of financing that is slightly different from the banking institutions in general, which is considered capable of providing business capital adequacy for the community after the Mount Kelud eruption, the financing pattern is the pattern of funding of the Grameen Bank model adopted from Bangladesh.

By using the financing pattern of the Grameen Bank model, people who are considered not bankable by financial institutions in borrowing or applying for credit can receive financing without binding conditions such as guarantees and other 
elements in $5 \mathrm{C}+3 \mathrm{R}$. Here the researcher is optimistic that the Grameen Bank pattern is very suitable to be applied to improve the economic conditions of the people affected by the Mount Kelud eruption because one of the main principles in the Grameen Bank is the answer to the problems of capital adequacy for the community. are: loans given without collateral or guarantors, loan procedures are made simple, loans are given to productive activities.

Not only is the problem of providing credit for disaster victims erupted, but the next problem that should be wary of when credit is disbursed is the risk of bad credit or default. This default event is also able to be minimized by the Bank Gremmen pattern because in principle the financing pattern applied to the Bnak Gremmen is jointly responsible. Someone to get a loan will and / or is repaying the loan will be supervised by other customers, because basically the loans to the Bank Gremmen are group.

\section{Community Service Program}

This community service program is an empowerment program for the Grameen Bank pattern for the community after the Mount Kelud eruption, while the impact of this program will have systemic impacts from various sides that are expected to increase the level of community welfare.
The Grameen Bank pattern is used to overcome the problem of a lack of capital from the community disasters caused by low access to banks because it is considered that the community is no longer bankable.

The pattern of the Grameen Bank program that will be used will be focused on the lower middle class people who have problems in accessing credit after the disaster, where previously they have had productive businesses before the disaster. It is hoped that by providing this working capital loan, community welfare can increase after the disaster. Briefly will be drawn as follows:

Figure 1

Grameen Bank Stages Pattern

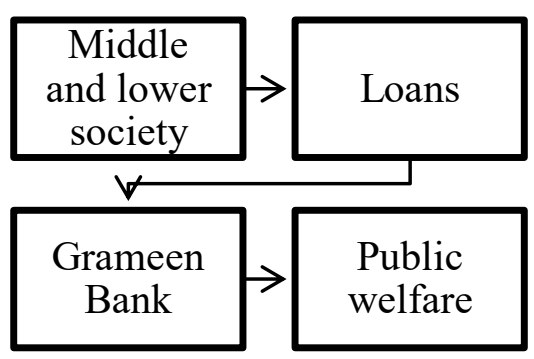

Source: Research Development

The Grameen Bank pattern program to be implemented has several stages as follows:

1. Before carrying out productive credit financing patterns, it is necessary to first classify the people who are the target of this financing pattern. Where the target of this pattern is the lower middle class people, victims of the Mount Kelud 
eruption disaster who have access to the banking world, where previously they included people who already had productive business activities.

2. After that, the management of the Grameen pattern held a public meeting by inviting local people, especially community and religious leaders, teachers, local government officials and others. The essence of the meeting was to provide a detailed explanation of the business activities of the Grameen Bank pattern.

3. The newly formed Grameen Bank administrators were based on a general meeting looking for prospective customers / members consisting of people who were victims of the Mount Kelud eruption who needed financial assistance where previously the disaster had productive business activities, by conducting due diligence on the candidates concerned. This activity is intended to guarantee that they truly fulfill the requirements set by the benchmarks regarding the objects of the Grameen Bank pattern.

4. For candidates who are deemed eligible to become members and given loans, it must form a group of 4 people who also meet the requirements. They must live close to one another and about the same age, socio-economic conditions, gender and educational background. In groups not allowed members who have close family ties such as: father, mother, brother, sister, brother-in-law, father-inlaw and so on. This group chooses the chairman and group secretary.

5. Several groups (2 to 8 groups) form one center. To lead the center a chairperson and a central vice chairman were chosen. Groups that are members of the center hold a meeting once a week, which is their own place and time.

6. The newly formed group must take part in compulsory group training. In group training it is taught about the philosophy and principles of the Grameen Bank, how to apply for loans and how to repay the loan. Those who are illiterate are taught to make signatures. In addition, a sense of solidarity between group members and discipline was also instilled, and motivated them to work hard.

7. At the end of the Group Compulsory Training (GCT) a group validation test is held. If they pass the exam, they are approved as Grameen Bank members and are entitled to apply for a loan.

8. A week later two members in the group received a loan. If they have repaid the loan for the specified time limit, two 
more members receive the loan. Furthermore, after the fourth (4) member has repaid the loan regularly for the specified time limit, the fifth member in the group receives the loan.

\section{Figure 2}

The Flow of The Loan Process at Grameen Bank

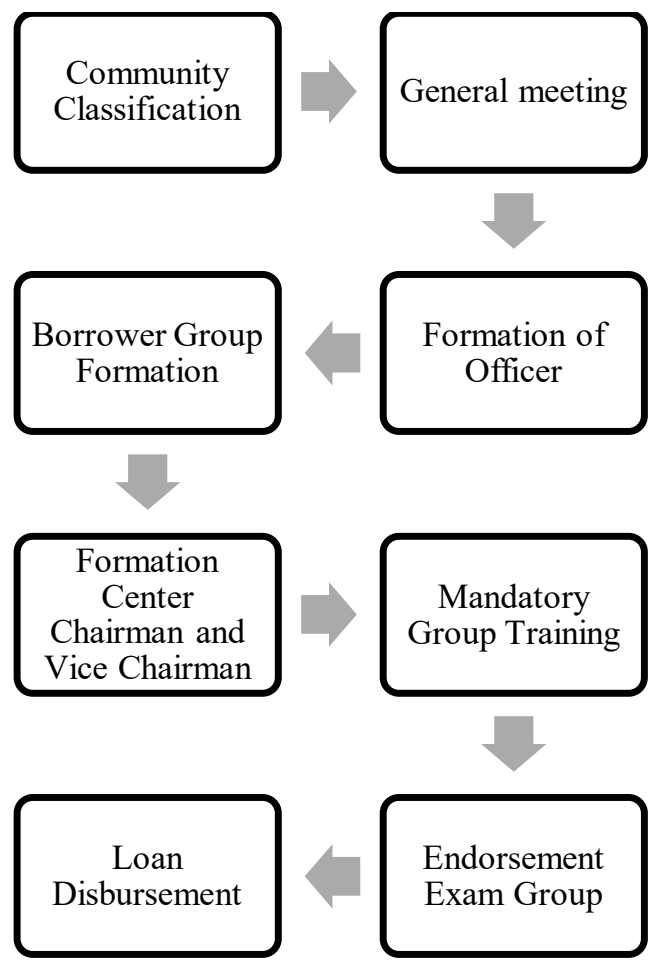

\section{Target Program}

The target program has two main parts where the writer calls it the two ultimate object, namely the main target and additional targets. The main objectives here are targets that must be realized or realized in the short term and the additional targets here are long-term goals after the main objectives can be achieved.

The main objective here is how to improve and strengthen the economic sector of the lower middle class Malang district after the eruption of Mount Kelud through the financing pattern of the Grameen Bank pattern. It is hoped that the community will be able to access productive financing to improve economic conditions after the eruption of Mount Kelud.

As for the additional objectives of this program, researchers grouped as follows:

\section{Ecology / Nature}

Malang district community affected by Mount Kelud eruption mostly as farmers and breeders. After the eruption of natural or ecological conditions in Malang district, it was severely damaged. With the existence of the Grameen Bank pattern financing program, it is expected that farmers and farmers can continue their productive activities. With the hope of getting better agriculture and plots in the area, it is actually unconsciously the nature that was originally devastated by a green back eruption by activities in the surrounding agricultural sector.

\section{Social Culture (Society)}

The strengthening of the economic sector with the Grameen Bank pattern can be felt to be very suitable with Indonesia because the system contained in financing is group and joint responsibility, so it is very clear that one with the other has a good level of attachment indicating that Indonesian 
having a high social nature which is a characteristic of national culture is not eliminated by financial institutions with the Grameen Bank pattern.

\section{Economy}

With the availability of productive financing assistance for the Grameen Bank pattern, it is certain that regional economic activities affected by the disaster of the Mount Kelud eruption will begin to move towards a positive trend.

With this loan, it is hoped that the economic activities of the people of Malang Regency which will be affected by the eruption of Mount Kelud will return to normal and tend to increase in the level of economic life, especially for the lower middle class.

\section{Well-Being}

Economic improvement in the community through the provision of productive credit in the short term is expected to be able to increase the productivity level of the people of Malang Regency, affected by the eruption of Mount Kelud, with increasing productivity of the community.

\section{Credit Distribution Mechanism}

Before starting the work, the bank sends a branch leader candidate along with aides to a certain area (Pandu Suharto, 1996: 9-10). The purpose is:
1. Make a map of the area that will be used as a branch office to be established, including the history, culture, economy and poverty conditions in that area.

2. After that, the bank held a public meeting by inviting local people, especially community and religious leaders, teachers, local government officials and others. The essence of the meeting is to give a detailed explanation of the business activities of the bank.

3. The officers of the newly formed Grameen Bank branch are looking for prospective customers / members consisting of people affected by the eruption who want to start a productive business but are hampered by capital, by means of due diligence of the candidates concerned. This activity is intended to ensure that they truly fulfill the requirements set by the Grameen Bank benchmark for poverty.

4. For candidates who are considered eligible to become members and given loans, then they must form a group of 4 people who also meet the requirements. They must live close to one another and about the same age, socio-economic conditions, gender and educational background. In groups not allowed members who have close family ties such as: father, mother, brother, sister, 
brother-in-law, father-in-law and so on.

This group chooses the chairman and group secretary.

5. Some groups (2 to 8 groups) form one center. To lead the center a chairperson and a central vice chairman were chosen. Groups that are members of the center hold a meeting once a week, which is their own place and time.

6. Groups that are formed must attend the Compulsory Group Training (CGT). In CGT it is taught about the philosophy and principles of the Grameen Bank, how to apply for loans and how to repay the loan. Those who are illiterate are taught to make signatures. In addition, a sense of solidarity between group members and discipline was also instilled, and motivated them to work hard.

7. At the end of the Group Compulsory Training (CGT) a group validation test was held. If they pass the exam, they are approved as Grameen Bank members and are entitled to apply for a loan.

8. A week later two members were in the .menhna loan group. If they have repaid the loan for one or two months, then two more members receive the loan. Furthermore, after the fourth (4) member has repaid the loan regularly for one or two months, the fifth member in the group receives the loan.

\section{Credit Return Mechanism}

The role of the Group has an important role as an institution that guarantees the responsibility of its members in repaying loans from all members. Thus members are under intense pressure from other members in the group. If any group member cannot pay installments due to inevitable problems then other members pay in advance the loan installments to the Bank, and later they bill the member concerned.

Payments are made when holding weekly meetings, where the meeting is better known as the central meeting or "center". Therefore, at the meeting Grameen Bank officers were also present because the Grameen Bank activities or transactions were carried out between the management and group members. In addition to receiving installments from members, Grameen Bank officers also collect Group Savings Funds and Emergency Funds to be deposited in the bank. Similarly, all loan matters are also discussed at meetings with bank officers.

The amount of group savings funds is $5 \%$ of the total loans received by each member that cannot be withdrawn. While emergency funds are set aside as much as 
$25 \%$ of the interest on loans that have been paid and deposited. As a special fund for central consultation, these funds can be used by members for various insurance purposes, such as life insurance, livestock insurance, and crop insurance. Its use is based on a decision determined by the central consultative council. Expenditures of emergency funds must be signed by the chairman of the meeting, the vice chairman of the meeting, and the manager. The utilization of the emergency fund must be signed together consisting of the head of the central meeting, vice chairman and branch manager.

Although Group Funds and Emergency Funds are not income from the bank, this amount is the effective cost to be paid by the borrower. According to Hossein in Pandu Suharto (1991: 63), by calculating these costs, the loan interest must be paid by the borrower instead of $16 \%$ but about $33 \%$ of the loan size.

\section{CONCLUSION}

Kelud eruption is a disaster that occurred in Malang Regency. The impact caused after the eruption, especially seen from the economic point of view, greatly influenced the level of welfare of the community, especially the people who were around the eruption. For this reason, treatment is needed to re-establish the economy that has been destroyed after the eruption of Mount Kelud. One solution offered by researchers is the provision of capital adequacy through the Grameen Bank pattern.

The Grameen Bank pattern is considered appropriate for disaster solutions and is divided into several things, namely: (i). The Grameen bank pattern is considered to be in accordance with the mindset and traditions of the people who are in Indonesia who adhere to mutual cooperation and family systems given that the prominent scheme in the bank's grameen pattern is joint responsibility, where the borrowing model has a relationship between borrowers and other borrowers. (ii) The Grameen Bank pattern is considered effective and productive in dealing with natural disasters that occur because the assistance program has only been short-term with the aim of providing assistance such as food and provision of temporary housing facilities, while the Grameen Bank pattern is a long-term solution because it provides working capital solutions to the community to re-establish their economic conditions again in the hope of returning to the level of welfare. 


\section{REFERENCES}

Adiatman, P.S; 1999. Peranan Kredit Sebagai Piranti Pengentasan Kemiskinan (Replikasi Grameen Bank di Indonesia), Skripsi, Jakarta: Sekolah Tinggi Ilrnu Ekonomi Perbanas, Jurusan Manajemen Keuangan.

Chotim, Erna Ermawati dan Tharnrin, Juni (ed.). 1997. Diskusi Ahli: Pemberdayaan \& Replikasi Aspek Finansial Usaha Kecil Di Indonesia. Yayasan AKATIGA, PEP-LIPI, Yayasan Mitra Usaha dan The Asian Foundation. Bandung.

Dede Haeruddin (Pyn), 1999. Aneka Skim Kredit Untuk Modal Usaha. Yayasaan Bhakti Kencana. Jakarta.

Firmansyah (2000). Implikasi Model Grameen Bank di Kabupaten Magetan, dalam bukunya "Pemberdayaan Usaha Kecil Melalui Grameen Bank" (Pny. Mahmud Thoha), PEP - LIPL Jakarta.

Gunardi, Harry Seldadyo Dkk, 1994. Kredit Untuk Rakyat. Akatiga. Bandung.

Rasahan, C.A. dan Syukur, M (1997), Karya Usaha Mandiri, Arah Baru Menjangkau Golongan Termlskin di Pedesaan, dalam Danusaputro, M., et.al., (1997), Monetisasi Pedesaan: Bunga Rampai Keuangan Pedesaan, Edisi Kedua, Jakarta: Institut Bankir Indonesia.

Sudaryanto, Tahlim, 1999. Perspektif Pembangunan Ekonomi Pedesaan Dalam Era. Pasar Bebas. Seminar Nasional Pembangunan Pertanian Dan Pedesaan Dalam. Era Otonomi Daerah. Bogor, 16 - 17 November 1999. Pusat Penelitian Sosial Ekonomi Pertanian Badan Penelitian dan Pengembangan Pertanian. Bogor.

Suharto, Pandu, 1989. Grameen Bank, "Sebuah Model Bank Untuk Orang miskin di Bangladesh".
Lembaga Pengembangan Perbankan Indonesia (LPPI), Jakarta.

1996. Petunjuk Pelaksanaan Sistem Perkreditan Grameen Bank di Indonesia. Jakarta: Yayasan Mitra Usaha, tidak dipublikasikan.

1996. 100 Tahun BPR Di Indonesia 1895 1995. InfoBank. Cetakan Pertama. Jakarta.

1998. Strategi Pengentasan Kemiskinan Melalui Bantuan Modal Bagi Rumah Tangga Miskin di Pedesaan, Rangkuman Hasil Penelitian. Jawa Timur. Malang. Lembaga Penelitian Universitas Brawijaya.

1998. Strategi Pengentasan Kemiskinan Melalui Bantuan Modal Bagi Rumah Tangga Miskin di Pedesaan, Rangkuman Hasil Penelitian. Jawa Timur. Malang. Lembaga Penelitian Universitas Brawijaya.

2012. APEX Bank. Bank Indonesia. Cetakan Pertama. Jakarta.

Hafid, A. 1997. Pelaksanaan Pola Grameen Bank di Bangladesh dan Malaysia, dalam Danusaputro, et al., "Monetisasi Pedesaan: Bunga Rampai Keuangan Pedesaan, Edisi Kedua, Institut Bankir Indonesia, Jakarta.

Supramono, Gatot, 1996.. Perbankan Dan Masalah Kredit "Suatu Tinjauan Yuridis". Cetakan Kedua. Penerbit Djambatan. Jakarta.

Thoha, Mahmud (Peny), 2000. Pemberdayaan Usaha Kecil Melalui Model Grameen Bank. Puslitbang Ekonomi dan Pembangunan - LIPI, Jakarta

Zain, Djumilah, 1993. Kaji Tindak Lembaga Keuangan Pedesaan Untuk Membantu Masyarakat Miskin di Kabupaten Malang dan Kabupaten Blitar, Usulan Penelitian, Malang. Lembaga Penelitian Universitas Brawijaya. 